\title{
ANALYSIS OF SIZE, ROA, AND GROWTH OF CORPORATE VALUE; WITH VARIABLE CAPITAL STRUCTURE AS INTERVENING
}

\author{
Rusnindita Kartika
}

UNIBA MADURA

Jl. Raya Lenteng No. 10, Kab. Sumenep, East Java 69451

krusnindita@gmail.com

\begin{abstract}
A B S T R A C T
The purpose of research to test the effect of SIZE, ROA, and GROWTH on Corporate Value, with Capital Structure as intervening variables in chemical base-based companies. The research approach uses quantitative approach with analysis tool uses SEM Wrap-PLS. The results of the research are: SIZE has a negative effect on Corporate Value; ROA has a positive effect on Corporate Value; Growth has no effect on Corporate Value; Capital Structure has a positive effect on Corporate Value; SIZE does not affect the Capital Structure; ROA has a positive effect on the Capital Structure; Growth has a positive effect on the Capital Structure; Capital Structure mediate indirectly positively between SIZE towards Corporate Value; The Capital Structure mediate positively indirectly between ROA and Corporate Value; Capital Structure mediate indirectly between Growth and Corporate Value.
\end{abstract}

Keywords: SIZE, ROA, Growth, Corporate Value, Capital Structure

Article History

Received 31 December 2019

Received in revised form 07 February $2020 \quad$ Accepted 07 June 2020

\section{Introduction}

Public company has a function to improve the glory of the owners or shareholders by raising corporate value[1], High corporate values play an important role for new companies or companies whose long pioneered accompanied by prosperous shareholders[2], Prosperous shareholders indicate if the company has a good corporate value, the presence of the shareholder and the company can be demonstrated by the stock price is known as an overview of the investment decision, financing, and asset management. Moreover, in determining corporate value was up or down, it is necessary to analyze a company's financial ratios and characteristics carefully and precisely so that when investing in a corporate can minimize the risk. Namely corporate profitability abilities in order to obtain an advantage in a certain period[3], Profitability describes the ability of a company that makes a profit by managing the entire asset and capital owned. Profitability including management effectiveness ratios are based on the results obtained through the rate of return sales, asset and investment[4], A high level of stock return is the reason investors infuse capital to the company. The higher the return on assets, it can raise the demand for the company's shares. Large profit could indicate a continuity of good corporate shareholders that is expected to raise demand for shares[5], The higher the company make a profit, so the larger the required return investors, which can potentially lead to better corporate value[6], Research Prasetyorini, (2013)explains that there is a positive effect on the profitability of corporate value. Company size (size) is also considered to determine corporate value. Firm size, the measurement of the weakness or strength of a corporate funding[4], Research Dewi and Wirajaya (2013) and Pantow et al., (2015)states if the larger scale or size of the company the more likely the company gets both internal and external sources of funding, financial resources obtained support operations thereby increasing the company's stock price. Stock price rose indicate that increasing corporate value, can be determined on the stock price that is listed on the Stock Exchange. If the stock price high indicates that the company can improve its performance and corporate value will rise[9], The growth of corporate development indicate future prospects. Companies experiencing high growth are likely to choose to use stock to finance the company's operations[4], Increased growth shows that the growth in obtaining the return on assets in the future. Research result Prasetyorini (2013) growth showed a positive influence to corporate value. Value companies are forecast on the overall every equity investor company related to the stock price. Stock price that is used based on the closing price, and as a price which occurs when the stock traded in the stock market[10], Corporate high value can increase investor confidence in the performance and viability of the company. Capital structure as a comparison between foreign capital and equity capital. The capital structure show permanent financing of a

* Corresponding author. Phone : +62 878-5539-4530.

E-mail address: krusnindita@gmail.com .

E-ISSN 2548-4214 
corporate financial proportion between debt includes short-term and longterm shareholder capital, as well as their own capital when running corporate activity. The capital structure has an important role in the company as optimal or suboptimal capital structure will have implications on the financial position of the company. The reason is because the researchers conducted the study found no difference (gap) in the earlier study that is not their Capital Structure as theoretical factors that influence the relationship between SIZE, ROA,,This is in accordance with trade-off theory which has a role in maintaining and controlling the targeted capital structure to maximize the function of the market value[11] and signaling theory is the attitude / responses were old owner shares that provide financial or non-financial information to investors regarding the company's performance and corporate value in the future, it is a signal / positive sign investors to invest their shares in the company[12].

\subsection{Table and Discussion}

The results of the tables needed in the results of the research are as follows:

Table 1. Fit models

\begin{tabular}{ll}
\hline Model fit indices & $\mathrm{P}$ values \\
\hline APC $=0193$ & $\mathrm{P}=<0.001$ \\
ARS $=0.124$ & $\mathrm{P}=1,099$ \\
AVIF $=1,057$ & Good if $<5$ \\
\hline
\end{tabular}

Results Table 1 shows that the output indicator of model fit with APC 0,193 with a p-value less than 0,001 , ARS 0,124 and $p$-value of 1,099 . AVIF value of 1,057 eligible is less than 5, the research data was tested with the model fit and declared fit research data so that the data of this study does not happen multikolirearitas.

Table 2. Path Coefficient

\begin{tabular}{|c|c|c|c|c|c|c|}
\hline & PBV & SIZE & \multicolumn{2}{|c|}{ GROWTH } & ROA & DAR \\
\hline R-Square & 0,110 & \multirow[b]{2}{*}{1,000} & \multirow[b]{2}{*}{1,000} & & \multirow[b]{2}{*}{1,000} & 0,138 \\
\hline Alpha & 1,000 & & & & & 1,000 \\
\hline $\begin{array}{l}\text { Combach } \\
\text { Full }\end{array}$ & & \multirow{3}{*}{1,036} & & & \multirow{3}{*}{1,131} & 1,000 \\
\hline $\begin{array}{c}\text { collinearit } \\
\text { y VIF }\end{array}$ & 1,038 & & \multirow[t]{2}{*}{1017} & & & 1,081 \\
\hline Q-square & 0,179 & & & & & 0,065 \\
\hline \multicolumn{7}{|c|}{ P-Values } \\
\hline & PBV & SIZE & GROWTH & ROA & \multicolumn{2}{|l|}{ DAR } \\
\hline PBV & & $\begin{array}{l}- \\
0,213\end{array}$ & 0,043 & 0,245 & 0,234 & \\
\hline \multicolumn{7}{|l|}{ SIZE } \\
\hline \multicolumn{7}{|l|}{ GROWTH } \\
\hline \multicolumn{7}{|l|}{ ROA } \\
\hline DAR & & 0,192 & 0,173 & 0,255 & & \\
\hline
\end{tabular}

The value of SIZE (size) with a p-value of 0,006 and a coefficient of 0,213; GROWTH (growth) in PVB (enterprise value) is not significant because the p-value greater than 0,05 ; SIZE (size) influence the DAR (capital structure) with a p-value of 0,149 and a coefficient of 0,192, SIZE (size) to DAR (capital structure) is not significant because the p-value greater than 0,05; while ROA (return on assets) to PBV (firm value) coefficient of 0,245 and p-value of 0,026; DAR (capital structure) to the PVB (enterprise value) coefficient 0,234, p-value 0,026; whereas GROWTH (growth) to DAR (capital structure) coefficient of 0,173 and pvalue of 0,012 ; ROA (return on assets) to DAR (capital structure) coefficient of $-0,255$ and DAR (capital structure) is less than 0,001.[1], Intervening variable capital structure (DAR) has an influence on corporate value $(\mathrm{PBV})$ with significance level.

Table 3. Method Variance accounted for (VAF)

\begin{tabular}{llc}
\hline & \multicolumn{1}{c}{ Effect of Total } & \multicolumn{1}{c}{ VAF } \\
\hline SIZE-DAR- & $0.0437+0.211$ & $0.0437 / 0.2547=0.1715$ \\
PBV & $=0.2547$ & \\
ROA-DAR- & $0.0575+0.28$ & $0.0575 / 0.3375=0.1703$ \\
PBV & $=0.1703$ & \\
GROWTH- & $0.0391+0.2$ & $0.0391 / 0.1609=-0.243$ \\
DAR-PBV & $=0.1609$ &
\end{tabular}

Capital structure (DAR) can mediate indirectly to the corporate value (PBV), so the value for SIZE VAF-DAR-PBV is 0,175; ROA-DAR-PBV is 0,1703 ; GROWTH-DAR-PBV is $-0,243$ of the three variables, VAF value $<20 \%$ is stated to have effect indirectly mediate. If VAF ranging between $20 \%-80 \%$ is said to be partial pemediasi[2]Hence, capital structure (DAR) may partially mediate between the size (SIZE), Return on Assets (ROA) and Growth (GROWTH) of the Company Value (PBV).

Table 4. Inner Model

\begin{tabular}{|c|c|c|c|c|c|}
\hline & PBV & SIZE & GROWTH & ROA & DAR \\
\hline PBV & & 0,006 & 0,235 & 0,026 & 0,026 \\
\hline \multicolumn{6}{|c|}{ GROWTH } \\
\hline \multicolumn{6}{|l|}{ ROA } \\
\hline DAR & & 0,149 & 0,012 & $<0,001$ & \\
\hline
\end{tabular}

Company Value (PBV) basic sectors of chemicals, R-square of 0,110 or $11 \%$, while direct relationship Return on Assets (ROA), size (SIZE) and Growth (GROWTH) to the Capital Structure (DAR) amounted to 0,138, or $13,8 \%$, which can be summed up their influence in the results of this research. The results show the value of the Q-Square predictive validity value> 0 then the research data already berkontruksi well have predictive relevance of Corporate Value (PBV) of 0,179 and Capital Structure (DAR) of 0,065. Assessment with Cronbach's Alpha test to Company Value (PBV) of 1,000. Full assessment with VIF collinearity on the variables of this study could otherwise avoid colinearity element for less than 3.3 .

\section{Illustrations Method}

Quantitative research methods in approach uses theories that supported the hypothesis determination. This study takes an object of research in the chemical sector industrial enterprises for BEI released one of the fastgrowing sector that is the basis of the chemical industry sector and by BEI report, the sector has increased by $21.17 \%$ year to date.Sample was taken using purposive sampling method. Research sample criteria include: (a) chemical sector companies listed on the Stock Exchange; (B) issuing stock company manufacturing the audited financial statement for the period 
ended 31 December 2012 to 2015; (C) the basic chemical sector industrial company that publishes financial statement with the use of the rupiah. Data analysis techniques with the use of PLS with completion method structual Equation Modeling (SEM) with 3.0 WarpPLS application usage.Mahfud Sholihin and Ratmono (2014) stated outer model is used in view of the validity and reliabilias. Outer outer loading the model value (valid when> 0,5 and ideally outer loading $>0,7$ ), average variance extracted (valid when>0,05), and composite realibility (when>0,8). Evaluation inner structural model or models created can be known right from the determinant coefficient (R2), predictive relevance (Q2), and Goodness Fit Index (GOF). Testing the hypothesis probability value and the value of t-statistic, using the p-value and alpha $5 \%$. T-table value alpha $5 \%$ was 1,96 . The criteria are:

a.Jika t-statistic value is smaller than t-table, then $\mathrm{HO}$ is accepted and $\mathrm{Ha}$ rejected.

b.Jika value of t-statistic greater than or equal to the $\mathrm{t}$-table, $\mathrm{H} 0$ is rejected and Ha accepted.

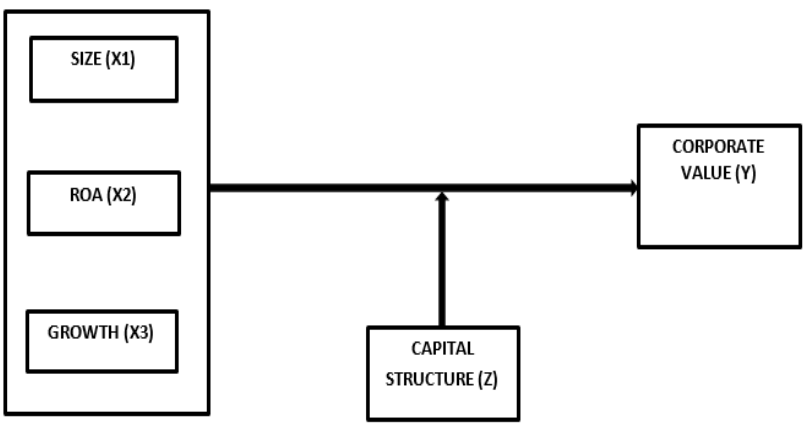

Figure 1. Research Model

\section{Equations}

Equation Research

$$
\mathrm{Y}=\mathrm{a}+\beta_{1} \mathrm{X}_{1}+\beta_{2} \mathrm{X}_{2}+\beta_{2} \mathrm{X}_{3}+\beta_{1} \mathrm{Z}_{1}+\beta_{3} \mathrm{X}_{1} \mathrm{Z}_{1}+\beta_{4} \mathrm{X}_{2} \mathrm{Z}_{1}+\beta_{5} \mathrm{X}_{3} \mathrm{Z}_{1}+\beta_{6} \mathrm{X}_{1} \mathrm{Z}_{2}
$$$$
+\beta_{7} X_{2} Z_{2}+\beta_{7} X_{3} Z_{2}+e
$$

Information:

$\begin{array}{ll}\mathrm{Y} & =\text { Corporate Value } \\ \mathrm{a} & =\text { constant } \\ \mathrm{X} \_1 & =\text { size } \\ \mathrm{X} \_2 & =\text { growth } \\ \mathrm{X} \_3 & =\text { Return On Asset } \\ \mathrm{Z} \_2 & =\text { Capital Structure (Mediation) }\end{array}$

\section{Results License}

Influence of company Size of the Corporate Value. Results of testing the effect of firm size to the Corporate Value stated that $\mathrm{H} 1$ is accepted and $\mathrm{H} 0$ is rejected, which means that the p-value of $<0,001$ and a coefficient of 0,21 , meaning Size negatively affect Corporate Value. Factors to determine the value of the company, can be seen in the indicators of the size of the company. When the size of the company has a large scale to allow the value of the company declined. of research Nuraina (2012) and Prasetia et.al. (2014) explained if the larger size companies can access the capital markets to be easier. The company has need the ability because funding from external parties access to the capital market more easily and to be flexible, when corporate or acceleration has easy accessibility to the capital markets means flexibility and corporate ability to bring greater funding[5], That is, a large-scale enterprise is considered to have ability to manage and bring huge potential funding from external parties for the survival of the company. Results of researchGaray and González (2008) and Dewi and Wirajaya (2013) explain corporate having a large size is easier to obtain a loan from external parties or third parties. Corporate debt obtained is used to invest, but the perception or thought of investors unwilling to take big risks when a company has excess debt so that corporate value will decrease. However, research Mahardhika (2016) The company explained that the size does not affect the Corporate Value.

ROA influence on the Corporate Value. The test results showed that ROA has a positive effect to the Corporate Value, so that $\mathrm{H} 2$ is accepted and $\mathrm{H} 0$ is rejected. Value P-value of 0,01 and a coefficient of 0,17 . High return on assets and on time will be able to see the prospects of the company's performance is good, so that it can attract investors to increase the value of shares in order to invest in a company. Moreover, it is said that the increase in the value of shares can also improve performance and corporate value. Theory signal / signal can strengthen the results of research which could lead to an increase in return of higher corporate value, so the company could give a positive signal to shareholders or investors to invest their shares in the company at the same time monitoring. Results research Sudjoko and Soebiantoro (2007) explained that the increase in earnings may show a signal if the company has good prospects in the coming time.

Growth Influence on Corporate Value. The test results stated that the $\mathrm{H} 3$ is rejected and $\mathrm{H} 0$ the p-value of 0,24 and a coefficient of $-0,04$ means Growth has no influence to the Corporate Value. The results of this reseacrh equal to reseacrh Q and Fidiana Daughter (2017)and Indra et al., (2013) say that growth does not have a negative effect on the value of the company. A decrease in the growth of corporate value cause remains decreased, because it does not affect the stock price. Not only known from only asset growth factor in determining corporate value for the growth of the company's assets are very volatile so growth not related to the value of the company. However, the result is different reseacrh research Sari and Priyadi (2017) which explains the growth of positive influence to corporate value.

Effect of Capital Structure on the Corporate Value. The test results explained if the capital structure has a positive impact on corporate value P-value of 0.03 and a coefficient of 0.23 , which means the $\mathrm{H} 4$ is accepted and $\mathrm{HO}$ is rejected. Signal Theory suggests that the higher the debt the company, it will increase corporate value. This is due to the use of debt to make the company grow and raise the company, resulting in higher stock price[22], In addition, their high capital structure is needed to determine the source of the initial capital and capital acquisition end of the company so that investors can predict corporate value in future periods. This research is consistent with the theory of signal that is the use of debt is well managed in the enterprise is a positive signal to investors that the company has the ability to expand its business. In other words, the higher the stock price also means increasing corporate value. 
SIZE influence on Capital Structure. The test results stated that H5 and $\mathrm{H} 0$ is rejected with p-value of 0,149 and a coefficient of 0,192 means that company size does not affect the capital structure. Corporate size can be determined by the value of the assets of the company, it does not affect the use of corporate debt in the capital structure so that the company is likely not optimal in running operations. When corporate with assets of many companies can manage these assets so well that corporate value will also automatically increase. However, when the size of the company is low, the value asest owned very little, then the investor would not believe it to companies to invest, resulting in decreased corporate value. The results of this research support research Prasetya (2014) which found a large or small corporate capital structure is not affected by. However, this study does not support researchSetyawan, Topowijono (2016) and Wiliandri (2011) who says that size has an influence on the capital structure.

The influence of ROA on Capital Structure. The test results explained that retrurn On Asset positive influence to the capital structure, so that $\mathrm{H} 6$ is accepted and $\mathrm{H} 0$ is rejected, with a p-value of $<0,01$ and a coefficient of 0,25 . Return on Assets increased their capital structure is followed by a high, and vice versa when ROA decreased the capital structure decreased. Research is in accordance with the Trade Off Theory, where a high corporate tax paid to the use of debt than exercising corporate tax payments low and declining capital structure[26], Companies that invest mostly embedded in fixed assets include current assets, will prioritize funding needs of permanent capital is capital itself while the debt is merely complementary. Results of researchSetyawan and Topowijono, (2016); andKhairin and Harto (2014) found high profit levels can cause high taxes, so that companies prefer to use debt financing on the benefits of interest as a tax deduction. Level of profitability and tax related to each other have a relationship because if corporate profit tax borne automatic height will be high anyway, so it tends to reduce corporate taxes by increasing the use of debt.

Effect of Growth of the Capital Structure. The test results explained that the Growth positive influence to the capital structure, so the $\mathrm{H} 7$ accepted and $\mathrm{H} 0$ is rejected with p-value of 0,001 and a coefficient of 0,17 . The company's growth is calculated by the amount of assets (current and fixed) or property owned. When corporate growth is getting better, the greater the capital structure management requires high current operating activities of the company, so the company needs a capital increase in the form of shareholder capital or debt of a third party. The use of debt in the capital structure of the company, because of the debt will be faster in the funding and finance the operations than the value of the shares. Corporate who continue to have good growth, the more easily the company in obtaining loans from creditors and the rapid growth of corporate could have an impact on the optimization of capital structure so it has the opportunity to implement more favorable investatiton. The results of this research in accordance with researchKhairin, Harto (2014) and Kartini, Arianto (2008) who argue that the level of growth can be achieved by managing the debt either in financing or capital structure the company so that in all operational activities aimed at improving the company's growth. However, this research is different from researchAlib (2015) explained that the growth does not affect the capital structure.
Capital Structure to intervening between the SIZE of the Corporate Value. The test results stated capital structure indirectly mediate between the size of the corporate value, so $\mathrm{H} 8$ accepted and $\mathrm{H} 0$ is rejected VAFnya value of 0,175 , or $17,5 \%$ means that the capital structure of positive indirectly mediate between the size of the corporate value. If the capital structure of companies includes the financing of external parties, the company has a requirement to pay interest expense and burden of principal, until it can be said if a corporate-sized tends to carry out expansion and business diversification more (the proceeds from the loan / debt) rather than corporate small, The results of this research in accordance Trade Off Theory where debt has an important role in raising the company and increase corporate value.[3], In addition, the optimal capital structure to support the formation of scale / size larger company so that corporate value will be good in the eyes of investors. Research result Siddik and Chabachib (2017); and Khoirunnisa et al. (2018) states sized corporate reputation and legitimacy is better, and tend to borrow money (debt) more, until the corporate value will be high because of their level of corporate growth while performing funds owned operating activities was derived from debt. However, it differs from research Ezeoha (2008), Which describes the company with old age and the growing tend to fund using their own capital without having had anything to do with external parties to increase corporate value.

Capital Structure to intervening between ROA on Corporate Values. The test results stated that the Capital Structure indirectly mediate between ROA on Corporate Value, so $\mathrm{H} 9$ accepted and $\mathrm{H} 0$ is rejected VAFnya value of 0,170 or $17 \%$ means that the Capital Structure of positive indirectly mediate between ROA on Corporate Value. The capital structure is: the balance between foreign capital include: long-term debt and short-term debt, with its own capital include: retained earnings and investment in the company's ownership. The existence of the debt has a benefit in developing performance and increase profitability of a company. When corporate profits have higher then the stock price will rise, so that the high corporate value[33], Additionally, optimization of the capital structure could support a smooth or achievement of the expected return on the assets that will increase corporate value. High profit company must have internal funding more than low berkeuntungan company. Corporate with a high rate of return will be invested with the use of a relatively small debt[34], Moreover, the high rate of return is possible in the financing of the majority of the funding needs through internally generated funds. This means that the profitability of influence to the company's capital structure. The results of this research in accordance with research Siddik and Chabachib (2017)were found to mediate ROA Capital Structure of the Corporate Value. However, this research differs from research Wulandari (2013) said Capital Structure can not mediate ROA on Corporate Value.

Capital Structure to intervening between Growth of the Corporate Value. The test results stated capital structure indirectly mediate between the Growth of the Corporate Value, so that H10 is accepted and H0 is rejected VAFnya value of -0.24 or $-24 \%$ Capital Structure means indirect negative mediate between the Growth of the Corporate Value. A corporate who suffer from decreased asset / wealth sometimes difficult to raise the value of the company and when the company has a high asset growth, most corporate tend to use internal funds or equity capital in the capital structure 
so that the debt can be decreased. In addition, the capital structure is not directly associated with the asset growth that impact on corporate value. The results of this research was supported research Darmawan (2015) and Astuti (2017) Growth Capital Structure mediate explain to the Corporate Value.All authors are required to complete the Procedia exclusive license transfer agreement before the article can be published, which they can do online. This transfer agreement enables Elsevier to protect the copyrighted material for the authors, but does not relinquish the authors' proprietary rights. The copyright transfer covers the exclusive rights to reproduce and distribute the article, including reprints, photographic reproductions, microfilm or any other reproductions of similar nature and translations. Authors are responsible for obtaining from the copyright holder, the permission to reproduce any figures for which copyright exists.

\section{Acknowledgements}

The conclusions of the study were (1). SIZE has a negative effect to the Corporate Value; (2) ROA has a positive influence on the Corporate Value; (3). GROWTH does not affect the Corporate Value; (4). Capital Structure has a positive influence on the Corporate Value; (5). SIZE does not affect the Capital Structure; (6). ROA has a positive influence on the Capital Structure; (7). GROWTH has a positive influence on the Capital Structure; (8). Capital Structure indirect positive mediate between the SIZE of the Corporate Value; (9). Capital Stucture positive indirectly mediate between ROA on Corporate Value; (10). Capital Structure indirect negative mediate between the GROWTH of the Corporate Value. Advice of the author are: For further research, the company is expected to reduce sample loss / bankruptcy; change the company objects studied and extend the period / year from previous observations using the latest / most recent; add other variables such as: dividend payment, cash flow, asset structure, liquidity and so on, so that the value of R-Square can be increased in value and the better research model; For management, is expected to determine the performance of companies in order to see the elements that affect the increase in corporate value, such as the distribution of dividends / profits to shareholders as well as the turnover rate in the company's assets and liabilities; while those investors, who will invest / invest their shares in a company.

\section{Appendix A.}

Operational Definition of Variables: Company size (SIZE) can be known through corporate shown the size of the total assets. SIZE $=\log$ [total assets]. Return on Assets (ROA) is the result on the amount of assets used in the activity of the company (both operational activities, funding, or investment) to profit after tax. Growth (Growth) companies can be measured by means of growth in the value of company assets. Asset growth is the difference between the total assets in the current period (now) with a year earlier to total assets in the current period. Measurement value (Corporate Value) using Price Book Value ratio. Price Book Value $=$ (market price per share outstanding) / (net book value per share outstanding $)$. Debt to Assets $=($ Total Debt $) /($ Total Assets $) \times$ $100 \%$.

\section{REFERENCES}

[1] D. Salvatore, Managerial Economics: Managerial Economics in a Global Economy -5 / E. Book 1. Jakarta: Four Salemba 2005.

[2] EF Brigham and PR Daves, Intermediate Financial Management 9th, SeaHarbor: The Dryden Press, 2007.

[3] S. Husnan, Basics Securities Portfolio Theory \& Analysis Ed. 5, Yogyakarta, 2015.

[4] S. Hermuningsih, "Influence Profitability, Growth, Opportunity, Capital Structure of the Company on the Company's Values In Public Companies in Indonesia. "Finances, vol. 16, no. 2, pp. 1-22, 2013.

[5] M. Nurhayati, "Profitability, Liquidity And Company Size Effect on Dividend Policy and Corporate Value Non Services Sector," End of the financial. Business, Vol. 5, no. 2, pp. 144-153, 2013.

[6] ASM Goddess and A. Wirajaya, "Effect of Capital Structure, Profitability and Size of the Company's Corporate Value," E-Journal of Accounting., Vol. 4, no. 2, pp. 358-372, 2013

[7] F. Prasetyorini, "The Effects of Company Size, Leverage, Price Earning Ratio and Profitability of the Company Value" Management Science., Vol. 1, no. 1, pp. 183-196, 2013

[8] MSR Pantow, S. Pure, and I. Trang, "Analysis of Company Growth, Size Peursahaan, returm on Assets and Capital Structure Of Listed Company Value in LQ 45," EMBA, Vol. 3, no. 1, pp. 961-971, 2015.

[9] D. Wulandari, "Influence of Profitability, Operating Laverage, Liquidity Cosmos Capital Structure Values Company as an intervening" Account. Analysis. Journal,vol. 2, no. 4, pp. 445-463, 2013.

[10]RAI Sari and MP Priyadi., "Effect of Leverage, Profitability, Size and Growth Opportunity Against Corporate Values," Ris science. Management., Vol. 5, no. 10, pp. 17-36, 2017

[11]A. Sartono, Financial Management: Theory and Applications 4th Edition, BPFE: Yogyakarta, 2009

[12]W. Widarjo, "The Influence of Intellectual Capital and Intellectual Capital Disclosure on Corporate Values," Financial Accounting., Vol. 8, no. 2, pp. 157-170, 2011.

[13]Mahfud Sholihin PD and DD Ratmono, SEM-PLS 3.0 For Relations With WarpPLS Nonlinear Social Research and Business, 2014.

[14]I. Ghozali and H. Latan, Partial Least Squares: Concepts, Techniques and Applications Using SmartPLS Program 3.0, Semarang, 2015.

[15]E. Nuraina, "The influence of institutional ownership and size of the company and the value of company's debt policy (Studies in companies listed on the Stock Exchange)," Accounting, Vol. 4, no. 1, pp. 51-70, 2012.

[16]TE Prasetia, P. Tommy, and IS Saerang, "Capital Structure, Company Size Value And Risk Of Automotive Company Company Listed on the Stock Exchange," EMBA, Vol. 2, no. 2, pp. 879-889, 2014.

[17]Garay U. and M. González, "Corporate Governance and Corporate Value: The Case of Venezuela," Corp. Gov. An Int. Rev., Vol. 16, no. 3, pp. 194 209, 2008.

[18]AR Budi Wahyu Mahardhika, "Analysis Of Its Characteristics Affecting The Value Of The Company In Manufacturing Companies Listed In Indonesia Stock Exchange (Idx) Year 2010-2014" balance, Vol. 8, no. 2, pp 23-47, 2016.

[19]Sudjoko and U. Soebiantoro, "Effect of Shareholding Structure, Leverage, Factor Against Internal and External Factors Corporate Values," Manaj. Entrepreneurship, Vol. 9, no. 1, pp. 41-48, 2007.

[20]F. Daughter Q and F. Fidiana, "Effect of Growth Opportunity, Ownership Structure Policy Against Debt and Corporate Values," Ris science. Manaj., Vol. 5, no. 10, p. 102-123., 2017.

[21]GK Indra, Suhadak, and Z. Arifin, "Analisis Effect Of Profitability (Profitability) And Level Of Growth (Growth) On Capital Structure And Corporate Values (Study on Real Estate and Property Company Listed in 
Indonesia Stock Exchange (BEI) The period from 2007 to 2011), "Adm. Business, vol. 7, no. 2, pp. 71-91, 2013.

[22]IM Sudana, Corporate Financial Management, Theory \& Practice, Erland, Jakarta, in 2011.

[23]BT Prasetya, "Influence of Profitability, Company Size, Growth Opportunity, Liquidity, Asset Structure, Business Risk and Non-Debt Tax Shield to Capital Structure of the Company Sub Sector Consumer Goods" Management Science, Vol. 2, no. 4, pp. 1341-1353, 2014.

[24]AIW Setyawan and NFN Topowijono, "The Influence of Corporate Size, Growth Opportunity, Profitability, Business Risk, Effective Tax Rate, Asset tangibility, Firm Age And Liquidity Of Capital Structure Company (Studies in Sector Corporate Property and Real Estate Listed on the Stock Exchange." Adm. Business, Vol. 31, no. 1, pp. 108-117, 2016.

[25]R. Wiliandri, "The Effect of Ownership and Corporate blockholder Size Of Corporate Debt Policy" Business Economy, Vol. 16, no. 2, pp. 95-102 2011

[26]Luke Setia Atmaja Theory and Practice of Financial Management, CV.Andi Offset: Yogyakarta, 2008.

[27]Khairin and P. Harto, "Effect of Growth Opportunity, Profitability, Fixed Asset Ratio and Capital Structure Against Market Risk," Diponegoro Journal. Accountant., Vol. 3, no. 2, pp. 767-778, 2014.

[28]Kartini and T. Arianto, "Ownership Structure, Profitability, Growth Assets and Company Size Of Capital Structure On Manufacturing Company," Financial Perbankam., Vol. 12, no. 1, pp. 11-21, 2008.

[29]YES Alib, "Effect of Asset Structure, Profitability, Growth and Size Of Capital Structure On Automotive Company," Science and Ris. Accounting, Vol. 3, no. 1, pp. 35-57, 2015.
[30]MH Siddik and M. Chabachib, "Effect of ROE, CR, SIZE, and Institutional Ownership Of Values Company With Capital Structure intervening variable," Diponegoro Journal. Management, Vol. 6, no. 4, pp. 1-15, 2017.

[31]F. Khoirunnisa, I. Purnamasari, and H. Tanuatmodjo, "Effect Of Capital Structure Of Corporate Values In Textile And Apparel" Bus. Manag. Educ., Vol. 3, no. 2, pp. 21-32, 2018.

[32]AE Ezeoha, "Corporate-Size and Corporate Financial Leverage Choice In A Developing Economy Evidence from Nigeria," J. Risk financ., Vol. 9, no. 4, pp. 351-364, 2008

[33]F. Syahadatina, "The Effect of Size and Structure of Capital Against Corporate Value The Mediated By Leverage," Science and Ris. management,vol. 4, no. 8, pp. 1-15, 2015.

[34]EF Brigham and JF Houston, Basics Of Financial Management Book 1 Essentials Of Financial Management ed 11, Four Salemba, Jakarta, in 2011.

[35]Febriansyah Dharmawan, "Influence of Profitability Analysis, Size and Sales Growth to Value Company with capital structure as an intervening variable (Data Analysis Panel on Mining Company listed on the Stock Exchange 2010-2013)," Diponegoro University, 2015.

[36]WW Astuti, "Influence of Profitability, Size And Sales Growth Against Values Company With Capital Structure intervening variable (Study at Manufacturing Companies Listed in Indonesia Stock Exchange)," University of Muhammadiyah Yogyakarta, 2017. 